\title{
THE IMPLEMENTATION OF RELAXATION AND DISTRACTION TECHNIQUES ON EXPERIENCING ANXIETY AMONG ADOLESCENTS IN EARTHQUAKE PRONE AREAS
}

\author{
Yunita Astriani Hardayati ${ }^{*}$, Mustikasari ${ }^{2}$ \\ 1. Mental Health Nursing, Faculty of Nursing, Universitas Indonesia (FIK UI) \\ 2. Mental Health Nursing Departement, Faculty of Nursing, Universitas Indonesia \\ * Correspondence: yunitaastri21@gmail.com
}

\begin{abstract}
Adolescents are a vulnerable group of mental health problem development after frequently being exposed to disaster-related information. Some studies show that adolescents living in earthquake-prone areas experience anxiety. Adolescents' untreated stress possibly causes mood disorders, eating disorders, and even anxiety disorder. Nursing intervention conducted to reduce anxiety consists of relaxation and distraction techniques. Relaxation techniques include deep breathing exercises and five-finger relaxation techniques. This case study aims to describe the change signs and symptoms of anxiety on adolescent in an earthquake-prone area that giving relaxation and distraction techniques. The subjects of this study were four high-school-adolescent-students suffering from moderate anxiety about the earthquake and were measured by the Hamilton Anxiety Rating Scale (HARS). The results reveal that anxiety levels of all subjects decrease with average HARS score is 11,5. It is concluded that relaxation and distraction techniques can use as one of therapy to reduce anxiety on middle adolescent in the earthquake-prone area. This case study is considered as essential reference material for practitioners who find a similar case in the practice setting.
\end{abstract}

Keywords: pre-disaster anxiety, earthquake, relaxation-distraction technique

International Journal of Nursing and Health Services (IJNHS), September 2019, Volume 2, Issue 3; Page 09-15

Received: 07 March 2019; Revised: 11 April 2019; Accepted: 29 April 2019

DOI: https://doi.org/10.35654/ijnhs.v2i3.105

\section{Introduction}

A natural disaster is an event causing threat or disturbance in human's life; the hazards are possibly caused by natural factors, such as earthquakes, tsunamis, floods, landslides, droughts, hurricanes, or volcanic eruptions (1). Every year 335 natural disasters occur in the world, affecting more than 95.6 million people and kill 9.97 million people. Eight thousand seven hundred thirty-three people died as a result of natural disasters, in which most of the world's natural disaster are floods, hurricanes, and earthquakes (2).

Indonesia is one of the Asian countries and one of five countries in the world that most frequently experiences natural disasters. It places Indonesia in the second-highest seismic-vulnerable country after China, with, on average, 6.97 magnitude earthquake (3). Anxiety, mood disorders, and post-traumatic stress disorder are the psychological effect of earthquakes. Study in 128 child and adolescent-earthquake survivors in the Republic of Haiti reveals that $13.28 \%$ of the survivors show anxiety symptoms (4). Age 
affects emotional states and ways of dealing with existing problems. Adolescents show signs of anxiety and depression that are heavier than younger age groups (school-age and pre-school children) (6).

In Indonesia, the Regulation of the Minister of Health of the Republic of Indonesia Number 25 of 2014, explains that adolescents are residents with an age range of 10-18 years. The number of adolescents reaches $18 \%$ of the population or as many as 43.5 million people (7). In adolescent Amygdala, a center of emotions such as anger and anxiety develops rapidly than the other regions of the brain that control emotions. Environmental experience contributes to adolescent's feelings more than to hormonal changes (8). Earthquake event in the various areas is one of the ecological experiences that can trigger anxiety.

Stuart (2012) defines anxiety as a vague or unclear concern that can be caused by various conditions such as helplessness, uncertainty, insecurity, and isolation. Research investigating pre-disaster stress, notably earthquake, in adolescent is still undoubtedly limited. Furthermore, a study in Indonesia reveals that adolescents living in earthquake-prone areas experience anxiety (9). Many studies show that adolescents can experience anxiety triggered by their direct or indirect experience of earthquakes, such as hearing or receiving information through mass media (10).

An adolescent with anxiety needs comprehensive treatment because if it is not handled correctly, it possibly develops into a mood or even eating disorders. Adolescents who have experience in fear can develop suicide or harmful behaviors, such as drug abuse, criminal actions, or sexual promiscuity (11). An Erikson theory (1950) explains that each individual must fulfill every development stage to achieve optimalpsychosocial development. This development phase runs continuously, in which failure in one step will be a negative result of this stage and will disrupt an individual's progress throughout his life (12). The various psychological problem such as confronting the behavior, lack of love, and antisocial behaviors including skipping school, drug and alcohol abuse, premature-sexual activity arises in adolescents as a form of trauma (13).

Negative impacts of anxiety possibly arise on the life and future of adolescents as the next generation. Therefore, anxiety interventions are compulsory to prevent adolescents' psychosocial problems. Nurses have a role in managing anxiety by conducting a nursing intervention. Nursing intervention in patients' anxiety aims to possibly detect strain and use relaxation and distraction techniques to control stress. Several possible methods to train anxiety sufferers are relaxation techniques consisting of deep breathing exercise, distraction technique (shifting situations), and five-finger relaxation techniques (14).

A previous study showed the relaxation and distraction techniques were effectively reducing anxiety. However, few studies focused on adolescents who experience pre-disaster-anxiety related to earthquakes. This case study is considered as essential reference material for practitioners who find a similar case in the practice setting.

\section{Objectives}

The study aimed to examine the effect of relaxation and distraction techniques. On improving the sign and symptoms of anxiety among adolescents who are living in earthquake-prone areas. 


\section{Methods}

A case study was applied in this study among four middle-aged adolescents, which expresses anxiety during earthquake-related interviews, which randomly selected from high school. The subjective data obtained were then validated by measuring anxiety using the Hamilton Anxiety Rating Scale instrument.

The authors conduct an assessment of anxiety level before and after providing intervention. The intervention consists of deep breathing relaxation techniques, distraction techniques, and five-finger relaxation techniques in 2 sessions of 2 meetings. Each session takes approximately 30-45 minutes.

\begin{tabular}{|c|c|c|}
\hline Session & Objectives & Nursing Intervention \\
\hline \multirow[t]{3}{*}{1} & $\begin{array}{l}\text { To investigate } \\
\text { the anxiety felt } \\
\text { by adolescents }\end{array}$ & $\begin{array}{l}\text { The adolescents are allowed to express their anxiety and perceived } \\
\text { concerns about earthquakes before nursing interventions are provided. }\end{array}$ \\
\hline & $\begin{array}{lr}\text { To } & \text { reduce } \\
\text { anxiety } & \text { with } \\
\text { deep breath } & \text { belaxation } \\
\text { techniques }\end{array}$ & $\begin{array}{l}\text { We trained to perform a deep breath in right ways: breathing through the } \\
\text { nose slowly to create maximal respiration (until the chest feels full) then } \\
\text { exhaling slowly through the mouth. }\end{array}$ \\
\hline & $\begin{array}{l}\text { To reduce } \\
\text { anxiety with } \\
\text { distraction } \\
\text { techniques }\end{array}$ & $\begin{array}{l}\text { - The adolescents are asked to identify their most favorite or comfortable } \\
\text { activities or hobbies (at home or school) } \\
\text { - Adolescents are encouraged to perform certain activities selected when } \\
\text { anxiety arises. }\end{array}$ \\
\hline 2 & $\begin{array}{l}\text { To reduce } \\
\text { anxiety with a } \\
\text { five-finger } \\
\text { relaxation } \\
\text { technique }\end{array}$ & $\begin{array}{l}\text { - The adolescents are asked to take a comfortable position and close } \\
\text { their eyes. } \\
\text { - First, touching the thumb with the index finger while remembering } \\
\text { pleasant physical activities } \\
\text { - Second, moving the inch with the middle finger while remembering } \\
\text { the loved one } \\
\text { - Third, touching the thumb with the ring finger while imagining } \\
\text { receiving the most memorable praise } \\
\text { - Finally, reaching the thumb with the little finger while imagining } \\
\text { staying in a preferred place }\end{array}$ \\
\hline
\end{tabular}

\section{Results}

Case 1, Ms. A revealed that she was anxious about an earthquake that triggered a tsunami because Banyuwangi was a coastal district and had experienced a tsunami in 1994. The most worrying thing when hearing earthquakes close enough was fear of separation from family and fear of death. After receiving the nursing intervention, she reports that anxiety symptoms, including difficulty concentrating, lethargic, and uptight. HARS score before intervention 27 and after intervention 8.

Case 2, Ms. B expressed fear caused by fear of house losing, being unable to continue her studies, and fear of death because he saw the victims and damage caused by the earthquake at the television and social media. Ms. L was afraid of being crushed by rubble if an earthquake happened at night while sleeping. After receiving the nursing intervention, she reports that anxiety symptoms are still felt include uptight, nightmares, and loss of interest. HARS score before intervention 25, after intervention 12.

Case 3, Mr. H revealed that he was worried because he did not understand how to save himself during an earthquake. Anxiety is especially felt when looking at victims of earthquakes both through television and social media. Efforts made by adolescents when experiencing anxiety are praying or just being silent. Anxiety symptoms that still 
felt after receiving nursing intervention are difficulty concentrating, frequent urination, and nausea. HARS score before intervention 23, HARS score after intervention 9.

Case 4, Mr. S expressed his anxiety when he heard about the news of the earthquake from television, especially if the location of the quake was close enough to where Mr. S lived. Stress increased when he saw the earthquake triggering several other disasters such as the tsunami or liquefaction. After receiving the nursing intervention, she has been anxiety, difficulty concentrating, feeling scared, and have a negative thought about the earthquake, rapid heartbeat, and headache. HARS score before intervention 24, after intervention 17.

During the interview, four adolescent showed higher tense face, not calm, restlessness, talking with high intonation and fast because they caused anxiety and fear experienced. In conclusion showed the symptoms of anxiety that arise include rapid heart rate, nausea, indigestion, feeling fear, loss of interest, and difficulty concentrating. One of them even had a nightmare. The average HARS score of adolescents before getting a nursing intervention to reduce anxiety is 24.7 , and after intervention 11.5 .

Graph 1. Anxiety score of adolescent before and after nursing intervention

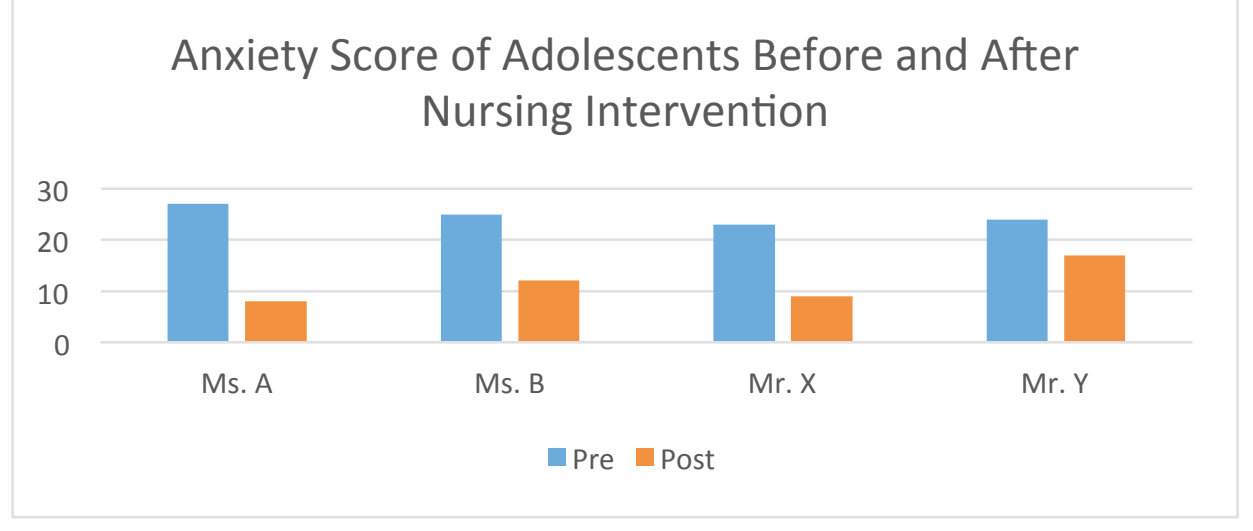

Graph 1 infers anxiety score of adolescents that live in an earthquake-prone area. It can be concluded that In this research's case, anxiety score decreases after the adolescents giving anxiety nursing intervention consist of relaxation and distraction techniques.

\section{Discussion}

From the interview, known that the adolescents particularly feel when they were receiving information about victim and damage caused by earthquakes through mass media. In line with the previous study showed that increasing the levels of fear of earthquakes when weather conditions are adverse, and they see images due to disasters or their past disaster experiences (15).

In cases, all four adolescents are in the middle range. Studies say that middleadolescents are had a high risk of experiencing anxiety. This is because when they move into adulthood, their mood becomes less extreme, and they adapt to hormone levels over time or to maturation from the prefrontal cortex, besides that environmental experiences can contribute more to adolescent emotions than hormonal changes (8). Earthquake events are one of the environmental exposures that affect anxiety in adolescents.

During interviews, the adolescents show anxiety signs such as tense faces, calmness, anxiety, and speaking with high and fast intonation because they exude anxiety and fear experience. When individuals experience anxiety, his body's response 
will work for fight or flight. This response often causes uncomfortable physical symptoms, such as an accelerated heart rate, rapid breath, and excessive sweat (16). They also reported signs and symptoms of anxiety, such as feeling scared and nervous. In line with research conducted on 3577 adolescents living in earthquake-prone areas showed signs of stress where $54.6 \%$ of adolescents were emotionally disturbed, $58.6 \%$ were frightened, and $60.0 \%$ were nervous about earthquakes (17).

Nurses, as health workers, have a considerable role in disaster management both before a disaster occurs, during an accident, and after a disaster. In cases, nurses have a coping role before an emergency occurs.

The management of anxiety was significantly impacting on disaster preparedness (18). Individuals who have experience in anxiety significantly reduce their preparedness for disasters (19), and individuals experiencing high anxiety have a higher risk of the impact of the disaster.

In the case, three adolescents, namely Ms. A, Ms. B, and Mr.X, have a significant change of signs and symptom of anxiety. They reported more relaxed, negative thoughts related to earthquakes reduced, the heart no longer pounding, can sleep, and digestive tract problem decreased. Relaxation techniques have the most effective not only for relaxation, lower heart rate, reduce body tension and negative thoughts, but also increase self-esteem and problem-solving skills (20).

Unlike the three others that can decrease anxiety symptoms until the free range of anxiety with a HARS scores below 14, Mr. X still reported anxiety symptoms like loss of interest, difficulty concentrating, feeling scared and having a negative thought about the earthquake, rapid heartbeat, headache. The results of the interview to Mr.X are known that for three days, Mr.X only practiced deep breathing relaxation techniques and distraction techniques without five finger relaxation technique.

Five-finger relaxation is a self-hypnosis providing a high relaxation effect, and thus, it will reduce stress and tension from individuals' thoughts (21). Five-finger relaxation effectively reduces anxiety. This mechanism supports the work of nerves sent by the brain or thalamus. Consequently, stress becomes information that can divert the attention of this information (22).

Mr.X also revealed that he practiced relaxation and distraction techniques only once a day for 30 minutes, while the other three adolescents did the exercises 2-3 times a day. Experts recommend doing exercises at least 2-3 times in at least 30 minutes to achieve maximal results. Though the first exercise might not show desired results, regular practices will enable the adolescents to feel the benefits (23).

\section{Conclusion}

The implementation of deep breathing exercise, distraction, and five-finger relaxation techniques for adolescents who lived in earthquake-prone areas are essential to decrease in adolescents' anxiety levels. Proper psychological preparedness is necessarily improved To reduce the risk of earthquakes among adolescent psychology. Furthermore, parents, teachers, and mass media must be aware of the adverse effects of media exposure to disasters on adolescents' psychological health.

Practitioners who find similar cases can employ all three techniques to reduce anxiety. It is recommended to apply the instruments to measure research subjects' anxiety. The Hamilton Anxiety Rating Scale is a rating scale to measure anxiety symptoms and is suitable for children, adolescents, and adults as research populations.

This study cannot conduct the post-test for two days after the intervention. The measurement of anxiety signs and symptoms will achieve more significant HARS score 
after the intervention. Also, providing sufficient time to practice relaxation techniques independently and conducting the analyses several days after the response will indicate real changes in anxiety signs of somatic symptoms.

\section{References}

1. Badan Nasional Penanggulangan Bencana. Definisi dan Jenis Bencana. 2018. https://www.bnpb.go.id/home/definisi;

2. Guha-sapir D, Hoyois P, Wallemacq P, Below R. Annual Disaster Statistical Review 2016 The numbers and trends Annual Disaster Statistical Review 2016 The numbers and trends. 2016;

3. Putra RR, Kiyono J, Ono Y, Arajuli HRP. Seismic hazard analysis for Indonesia. J Nat Disaster Sci. 2012;33(2):59-70.

4. Derivois D, Mary J, Eva N, Karray A. Child Abuse \& Neglect Prevalence and determinants of post-traumatic stress disorder, anxiety and depression symptoms in street children survivors of the 2010 earthquake in Haiti, four years after . Child Abuse Negl [Internet]. 2017;67:174-81. Available from: http://dx.doi.org/10.1016/j.chiabu.2017.02.034

6. Purnamasari I. Perbedaan reaksi anak dan remaja pasca bencana. 2016;49-55.

7. Infodatin Pusat Data dan Informasi Kementerian Kesehatan RI. 2012. www.depkes.go.id/download.php?file.../infodatin\%20reproduksi\%20remaja-ed.pdf

8. Santrock JW. Life-span development. McGraw-Hill; 2013.

9. Marthoenis, Meutia I, Fathiariani L, Sofyan H. Prevalence of depression and anxiety among college students living in a disaster-prone region. Alexandria J Med [Internet]. 2018;2-5. Available from: https://linkinghub.elsevier.com/retrieve/pii/S2090506818300095

10. Pfefferbaum B, Newman E, Nelson SD, Nitiéma P, Pfefferbaum RL, Rahman A. Disaster Media Coverage and Psychological Outcomes: Descriptive Findings in the Extant Research. Current Psychiatry Reports. 2014.

11. Stafford B, Schonfeld D, Keselman L, Ventevogel P, López Stewart C. The Emotional Impact of Disaster on Children and Families. Available from: https://www.aap.org/en-us/Documents/disasters_dpac_PEDsModule9.pdf

12. Videbeck SL. Psychiatric Mental Health Nursing Fifth Edition. 5th Editio. Lippincott Williams \& Wilkins; 2011. 48 p.

13. Gaffney DA. The Aftermath of Disaster : Children in Crisis. 2006;62(8):1001-16.

14. Keliat, B.A, Wiyono, Akemat. P.W dan Susanti, H. (2015). Manajemen Kasus Gangguan Jiwa CMHN (Intermediate Course). Cetakan 5

15. Cvetkovi VM, Öcal A, Ivanov A. International Journal of Disaster Risk Reduction Young adults ' fear of disasters : A case study of residents from Turkey, Serbia, and Macedonia. Int J Disaster Risk Reduct [Internet]. 2019;(August 2018):101095. Available from: https://doi.org/10.1016/j.ijdrr.2019.101095

16. Farra SL, Cne RN, Smith SJ, Cnl RN. Anxiety and Stress in Live Disaster Exercises. J Emerg Nurs [Internet]. 2019;1-9. Available from: https://doi.org/10.1016/j.jen.2019.01.012.

17. Yeung NCY, Lau JTF, Yu NX, Zhang J, Xu Z, Choi KC, et al. Media exposure related to the 2008 Sichuan earthquake predicted probable PTSD among Chinese adolescents in Kunming, China: A longitudinal study. Psychol Trauma Theory, Res Pract Policy. 2018;10(2):253-62.

18. Pfefferbaum B, Shaw JA. Practice parameter on disaster preparedness. J Am Acad 
Child Adolesc, Psychiatry. 2013;52(11).

19. Mishra S, Suar D. Effects of Anxiety, Disaster Education, and Resources on Disaster Preparedness Behavior. J Appl Soc Psychol. 2012;42(5):1069-87.

20. Katharina Star. Verywellmind. Popular relaxation technique for anxiety. 2018. https://www.verywellmind.com/popular-relaxation-techniques-2584192.

21. Hastuti RY, Arumsari A. Pengaruh terapi hipnotis lima jari untuk menurunkan kecemasan pada mahasiswa yang sedang menyusun skripsi di STIKES Muhammadiyah Klaten. Motorik. 10(Nomor, 21).

22. H Dewi, Aulia Prastika. 2019. Aplikasi Terapi Hypnosis Lima Jari Dalam Manajemen Cemas Pada Asuhan Keperawatan Pasien Pre Operasi Laparatomi di Rumah Sakit Roemani Muhammadiyah Semarang. http://repository.unimus.ac.id;

23. NHS. (2018). Relaxation Technique https://www.nhsinform.scot/healthyliving/preventing-falls/fear-and-anxiety-about-falling/relaxation-techniques 